\title{
Estimating the economic loss of recent North Atlantic fisheries management
}

\author{
Gorka Merino $^{\mathrm{a}, \mathrm{b}, *}$, Manuel Barange ${ }^{\mathrm{b}}$, Jose A. Fernandes ${ }^{\mathrm{b}}$, Christian Mullon $^{\mathrm{c}}$, William Cheung ${ }^{\mathrm{d}}$, \\ Verena Trenkel $^{e}$, Vicky Lam ${ }^{f}$
}

a AZTI-Tecnalia, Herrera Kaia, Portualdea, z/g, Pasaia (Gipuzkoa), 20110, Spain

b Plymouth Marine Laboratory, Prospect Place, PL1 3DH, Plymouth, UK

c IRD, Unité de Recherche Ecosystémes Marins Exploités, Avenue Jean Monnet, 34200, Séte, France

d Fisheries Centre, University of British Columbia Fisheries Centre, Vancouver, B.C., V6T 1Z4, Canada

e Ifremer, rue de l'ile d'Yeu, BP 21105, 44311 Nantes cedex 3, France

f Fisheries Economics Research Unit, Fisheries Centre, University of British Columbia Fisheries Centre, Vancouver, B.C., V6T 1Z4, Canada

*: Corresponding author : Gorka Merino, tel.: +34 667-174-456 ; email address : gmerino@azti.es

maba@pml.ac.uk ; w.cheung@fisheries.ub.ca ; Verena.Trenkel@ifremer.fr ; v.lam@fisheries.ub.ca

\begin{abstract}
:
It is accepted that world's fisheries are not generally exploited at their biological or their economic optimum. Most fisheries assessments focus on the biological capacity of fish stocks to respond to harvesting and few have attempted to estimate the economic efficiency at which ecosystems are exploited. The latter is important as fisheries contribute considerably to the economic development of many coastal communities. Here we estimate the overall potential economic rent for the fishing industry in the North Atlantic to be $B € 12.85$, compared to current estimated profits of $B € 0.63$. The difference between the potential and the net profits obtained from North Atlantic fisheries is therefore $B € 12.22$. In order to increase the profits of North Atlantic fisheries to a maximum, total fish biomass would have to be rebuilt to $108 \mathrm{Mt}$ (2.4 times more than present) by reducing current total fishing effort by $53 \%$. Stochastic simulations were undertaken to estimate the uncertainty associated with the aggregate bioeconomic model that we use and we estimate the economic loss NA fisheries in a range of 2.5 and 32 billion of euro. We provide economic justification for maintaining or restoring fish stocks to above their MSY biomass levels. Our conclusions are consistent with similar global scale studies.
\end{abstract}

\section{Highlights}

- The economic loss of North Atlantic fisheries in 2010 was B€ 12.2. Fish stocks would have to recover to levels 2.4 times larger than present to achieve maximum profits. Macroscale assessments of governance require simplifications and assumptions. Stochastic simulations estimate NA fisheries loss in a range from $B € 2.5$ to $B € 32$. Securing that stocks biomass are above MSY is economically justified despite uncertainty on results.

Keywords : Economic assessment ; Fisheries, North Atlantic ; Management efficiency ; Uncertainty 
56 Marine fisheries are an important source of food and livelihood opportunities worldwide 57 (Allison et al., 2009; Garcia \& Rosenberg, 2010; Rice \& Garcia, 2011). The exploitation state of 58 fish stocks is hotly debated (Branch et al., 2011; Pauly et al., 2002; Worm et al., 2009), but there 59 is a general consensus that marine fisheries food production potential is not achieved (Branch et 60 al., 2011; FAO, 2012). North Atlantic fisheries are nowadays yielding less fish than in recent decades and despite significant improvements (Fernandes and Cook 2013), the state of many of

62 its stocks remains poor._Traditionally, the efficiency of biomass production has been the basis of 63 fisheries management. Therefore, different regulations have aimed at maintaining fish stocks at 64 levels at which they could produce their Maximum Sustainable Yield (MSY), i.e. the exploitation 65 rate where the response of the stocks to fishing through individual growth and recruitment operates at its maximum capacity. In a deterministic sense, at this level, average fish biomass remains stable over time and the amount of fish that can be sustainably extracted is maximized (Schaefer, 1954). Classic approaches assume that these dynamics operate at a particular stock level, depending on the species' life history and thus, should fisheries management succeed in maintaining each of them at their MSY, the maximum potential of food production from marine ecosystems would be achieved. Using Economic Exclusive Zone (EEZ) and fish species data from the Sea Around Us database, the food production potential wasted due to ineffective management was estimated, i.e., the difference between catch observations and their MSY estimated from historic catch series (Srinivasan et al., 2010). Srinivasan et al. (2010) estimated that catch losses amounted to $7-36 \%$ of the reported annual catch, resulting in a landed value loss between $\$ 6.4$ billion and $\$ 36$ billion.

In reality, it is ecologically impossible to simultaneously maximize sustainable yield for all 79 species in a multiple species fishery (Link, 2009). Therefore, the productivity of marine 80 ecosystems is expected to be lower than predicted by the sum of single stocks' MSY (Link et 81 al., 2012). The overall productivity and state of exploitation of marine ecosystems have been 82 investigated previously with complex ecosystem models and indicators (Blanchard et al., 2012; 83 Blanchard et al., 2009; Coll et al., 2008; Cury et al., 2008; Merino et al., 2012; Shin et al., 84 2005), and with single species models applied to entire exploited communities (Guillen et al., 85 2013; Link et al., 2012; Mueter \& Megrey, 2006; Sparholt \& Cook, 2009; Worm et al., 2009). 86 For example, 'surplus production models' (SPM), have been used to produce simple 87 representations of the key ecological processes underlying fisheries (Link et al., 2012). SPM can 
88

89

90

91

92

93

94

95

96

97

98

99

100

101

102

103

104

105

106

107

108

109

110

111

112

113

114

115

116

117

118

119

120

121

122

123

124

be used to estimate biological reference points (BRP's) such as the biomass level and the rate of exploitation to achieve the MSY of single fish stocks or marine ecosystems.

SPM have allowed the extension of fisheries assessment into other disciplines beyond ecology. For example, the seminal paper by Gordon (1954) introduced the concept of Maximum Economic Yield (MEY), the bioeconomic reference point at which the economic profits of a fishery are maximized. This concept relies on fish stocks' productivity described by SPM (Schaefer, 1954), the market price of fish and the costs of fishing. A derivation of this model was used to assess the economic efficiency at which the world's fisheries are exploited (Arnason et al., 2009), from which global MEY was estimated based on world's catch, value and costs databases. Arnason et al (2009) highlight the vast economic consequences of inefficient fisheries management and the economic benefit of maintaining fish stocks at healthy levels. Due to the high uncertainty in the data and the simplified model used, the numeric results of Arnason et al (2009) study were presented with caution and with wide confidence intervals. Nonetheless, the global cost of sub-optimal management was estimated to be in a range between \$37-67 billion in 2004, with an historic accumulated loss of \$2.2 trillion between 1974 and 2004. Arnason et al. (2009) did not explicitly evaluate the cost of rebuilding fish stocks, i.e., the cost of the necessary transition until stocks are recovered and more economic profit is obtained with less fishing effort. More recent research shows that the benefit of rebuilding global fisheries outweighs costs (Sumaila et al., 2012) and that investing in restoring overexploited stocks is economically sound (Crilly \& Esteban, 2012). However, it is important to clarify that not all fish stocks are overexploited. For example, forty-three percent of assessed EU stocks were considered overfished in 2012 (Fernandes \& Cook, 2013; European Union 2012). In any case, when fishing yields do not correspond to MSY this does not automatically mean a stock is overfished (Hilborn \& Stocks, 2010). Hilborn and Stokes (2010) suggest that it would be reasonable to adopt a definition of being overfished as any stock size where the expected yield is $80 \%$ or less than MSY, which is the level at which reductions of fishing mortality towards MSY would produce measurable catch increases.

The North Atlantic basin is a dynamic environment for physical and biological processes (Beaugrand et al., 2002; Marshall et al., 2001; Parsons \& Lear, 2001) and is home to some of the largest populations of commercially exploited stocks (Trenkel et al., 2013). With this at the background and due to the importance of North Atlantic global climate, BASIN (Wiebe et al., 2009) is a joint EU/North American research initiative with the goal of elucidating the mechanisms uderlying observed changes in the North Atlantic ecosystems and their services, and Euro-BASIN is a programme to implement this vision funded by the European Commission $7^{\text {th }}$ Framework Programme (St. John et al. introduction article of this issue). In the context of 
Euro-BASIN, this article aims to reflect the economic relevance of fisheries within the North Atlantic basin using some of the methods described above to estimate the economic cost of ineffective fisheries management, defining 'ineffective' as a deviation from maximum economic rent (Arnason et al., 2009). To do so, we tested alternative aggregations of fisheries production and economic indicators and parameterized a simple bioeconomic model. The scope and scale of this study is vast and complex and requires simplifications. The ecological complexity, regional differences and dynamics of individual fish stocks in the North Atlantic are simplified in an aggregated single stock of fish, which is exploited by an aggregated single fishery. While this approach has significant ecological difficulties, aggregated fisheries production functions are not new, and have been used to assess the economic efficiency of global fisheries as a single exploited unit (Arnason et al., 2009), at ecosystem level (Crilly \& Esteban, 2012; Link et al., 2012; Sparholt \& Cook, 2009) and at species-EEZ level (Srinivasan et al., 2010). The implications of this approach and justification for the use of an aggregated model will be discussed in detail throughout the manuscript. Furthermore, we explore the possible impact of parameter uncertainties and the assumptions made to obtain our numeric results. Finally, we discussed the use of multidisciplinary approaches in analyzing marine resources at the basin scale. These results provide background context to the work conducted in Euro-BASIN in the Bio-economic modeling (WP7) and Living resources (WP5) workpackages.

\section{Material and Methods}

\subsection{The data}

- Biological parameters: Catch data from ICES FishStatPlus database (www.ices.dk), FAO Fishery Statistics (www.fao.org) and Sea Around Us catch database (www.seaaroundus.org) were used to estimate the biological parameters of the surplus production model of the North Atlantic (NA) fisheries from 1950 to 2010. The data used comprise 59 ICES stocks, 18 species and 2 habitats exploited in the North Atlantic for the ICES area (see Table 1). These data were used to explore how alternative levels of stock and taxonomic aggregation could lead to different MSY estimates and indicate the uncertainty that the aggregation process undergone for the NA bioeconomic model. The overall NA basin MSY was estimated using datasets from FAO and was used as input for the bioeconomic model. A series of all the species landed in the NA was used.

- Economic parameters: Three main sources of information were used to obtain the economic parameters of the NA fisheries. First, the Sea Around Us database was used 
to obtain the value of the NA fishery as a whole. Second, a global fishing costs database at fleet segment level (Lam et al., 2011) was used to estimate countries total profits (Table 2). These estimates showed significant differences with the ones reported in the Annual Economic Report of the European Fishing Fleets (JRC, 2012).

166

\subsection{The models}

168

- Biological parameters estimation: We used a relatively simple method to obtain plausible MSY estimates and other biological parameters from catch data, based on assumptions on resilience (corresponding to the intrinsic growth rate $r$ in the SPM) and the plausible range of relative stock sizes at the beginning of the time series (Martell \& Froese, 2010). We used a medium resilience range as defined by Martell $\&$ Froese, i.e. $0.2<r<1$, and an initial (in 1950) relative stock size range of $50-90 \%$ of carrying capacity $K$ or pristine biomass for all stocks (except for 'ghl-arct' ICES stock which was considered of 'low' resilience, $0.05<\mathrm{r}>0.5$ ), and all species, habitat and the total NA. The identification of pairs of $r$ - $K$ values compatible with the catch time series and the above assumptions was performed using the R-code for batch processing made publicly available in http://www.fishbase.de/rfroese/CatchMSY_2.r for 59 ICES stocks ('ICESct2.csv', catch file processed and also made available by Martell and Froese), for the 18 species targeted in the ICES areas and for the entire NA basin from FAO catch data. The aggregation was a simple summation of catches of all the stocks of each of the 18 species, of all demersal and pelagic species and of all ICES stocks. Similarly, for the NA estimation, all NA species catches were summed to obtain a single catch time series. For each plausible $r$ - $K$ pair, an estimate is obtained as MSY $=1 / 4 r K$. This MSY estimation algorithm has been validated against analytical fish stock assessment estimates of MSY (Martell \& Froese, 2010). Good agreement was found between stock assessment MSY estimates and the geometric mean of MSY values calculated from the plausible r-K pairs (Martell \& Froese, 2010).

Aggregated bioeconomic model (Arnason, 2007; Arnason et al., 2009). This model assumes that the stocks exploited by global fisheries can be modeled as a single fish stock with an aggregate biomass growth function and a fishing industry operating exclusively in the area. The economic performance from fisheries is estimated with the value of the global landings calculated with an aggregated harvest function (SPM by Schaefer 1954) and an aggregated fishing cost function relating current fishing effort to fisheries costs. Incorporating NA fisheries into a single fishery allows for a model with a manageable number of parameters. This model requires 4 biological parameters: (i) 
Global MSY, (ii) total 'carrying capacity' or 'unexploited biomass level', (iii) fish biomass growth in the last year and, (iv) a 'schooling' parameter; and 5 economic parameters from the fishing industry: (i) Landings, (ii) value of landings and, (iii) total profits from fishing in the last year, (iv) 'fixed costs ratio' and, (v) 'elasticity of demand' with respect to total biomass. The MSY has already been explained and 'unexploited biomass', fish biomass growth, landings, value of landings and profits are self-explanatory. The 'schooling' parameter describes the spatial distribution behavior of fish and ranges between 0 and 1 . The lower the parameter the more aggregated the fish, e.g., small pelagic stocks like anchovies, sardines, mackerel etc. When this parameter is close to 1, fish are homogeneously distributed in space, e.g., demersal species such as hake or plaice. For our analysis we fixed this parameter as 1 , to assume that all fish are homogeneously distributed throughout the NA. However, the impact of this parameter on the final calculations is explored in the Appendix. The 'fixed costs ratio' describes the fraction of the total costs incurred by the fishing industry that are not originated by labor, fuel, capital and other factors of production such as maintenance, repair, supplies and gear costs. We considered this ratio to be 0 as in the global study (Arnason et al., 2009). Assuming a zero value means that fishing effort is measured as the size of fishing industry and not by its activity (if inactive, fleets would still generate fixed fishing costs). The elasticity of demand to biomass expresses the price of fish as dependent on the global marine commercial fish biomass. This elasticity is positive: when there is overexploitation, biomass is at a low level, the proportion of low value fish is higher and mean price is smaller; in the other direction, if fish stocks recover from overexploitation, the average size and trophic level of caught fish increased and price does so likewise. This is a manifestation of the "fishing down the food web" effect (Pauly et al 1997).

The bioeconomic model also required additional input that was obtained as follows: from the FAO catch data series we obtained catches in $2010\left(\mathrm{Y}_{2010}\right)$ and biomass growth in $2010\left(\mathrm{G}(\mathrm{x})_{2010}\right)$. We used the difference between $\mathrm{Y}_{2010}$ and $\mathrm{Y}_{2009}$ as $\mathrm{G}(\mathrm{x})_{2010}$ which assumes that catch changes were only caused by abundance changes rather than management or other factors. For the value of catches, the Sea Around Us database was used to complement FAO data (Value 2010 ). The profits of NA fisheries in 2010 was obtained summing the national profits (Table 2) obtained from Lam et al (2011) applied to NA value of catch.

( \# Insert Table 2 \#) 
We plot the classical equilibrium catch-biomass curve (Schaefer, 1954) and different potential profit curves (iso_ $\Psi$ ) defined by the profits in $2010\left(\Psi_{2010}\right)$, price at equilibrium $\left(\mathrm{p}_{\mathrm{eq}}\right)$, costs of fishing per unit of effort (c) and biomass at equilibrium (equation 1).

iso $-\Psi=\frac{\Psi_{2010}}{p_{e q}-c \cdot B_{e q}}$ (equation 1)

The points where $i s o_{-} \Psi$ trajectories meet the catch and biomass equilibrium curve are a feasible sustainable profit, catch and biomass equilibrium points. The maximum feasible iso_ $\Psi$ is searched to identify the $M E Y$ of North Atlantic fisheries. Further transformations of the basic equations by Gordon-Schaefer required to plot the curves are explained in the Appendix. Economic loss is then calculated as the difference between this MEY value and realized profits in 2010.

Stochastic simulations: The economic loss estimated with the deterministic model for 2010 was re-estimated allowing for uncertainty on the input parameters (Table 3): (i) random values in a range of $\pm 30 \%$ of the initial parameters ('sim 1'), (ii) lognormal distributions for MSY and $\mathrm{K}$ as provided by the Martell and Froese (2010) estimation model and random for the others ('sim 2'), (iii) lognormal distributions for MSY and K and random for Catch 2010 ('sim 3') and, (iv) random within $\pm 30 \%$ for all parameters but MSY, $K$ and Catch 2010 which were kept constant ('sim 4'). For all stochastic simulations the model was run for $10^{5}$ iterations to equilibrium.

\section{Results}

The total MSY for all the ICES stocks combined was estimated to be between 6.68 and 9.75 million tonnes, depending on the level of catch aggregation from which the estimates were calculated (Table 1 and Figure 1).

Biological parameters were estimated for each of the ICES stocks and were then aggregated into species, habitat and total ICES areas. The total MSY estimate for the ICES fisheries decreases exponentially with the level of aggregation, with MSY estimates 30\% lower when using ICES area aggregation (largest aggregation) compared to estimates from stock level aggregation (lowest aggregation). Although we don't use the estimated MSY by ICES area for the basinscale analysis, the differences between estimates arising from different levels of aggregation were used to calculate the confidence limits of MSY in the North Atlantic, which were used as inputs for the bioeconomic model.

\section{( \# Insert Figure 1 \#)}


273 We used the time-series of total aggregated NA landings applied to the algorithm by Martell and 274 Froese (2010) to estimate an MSY of 13.7 Mt (s.d.=0.04) (Figure 2). Historically North Atlantic 275 fisheries were considered to be under development up to 1970s, when total landings started to 276 exceed MSY considerations. From 1980 until the early 2000s, the total catch has fluctuated near 277 this estimated global MSY. Since then landings have decreased to levels approximately $80 \%$ of 278 basin MSY. This model also estimated the carrying capacity parameter (K) or unfished biomass 279 for North Atlantic fish resources to be 170 Mt (Table 3).

280

281 ( \# Insert Figure 2 \#)

282 The bioeconomic model estimated that NA fisheries could generate $\mathrm{B} € 12.85$ of profits compared to the current $\mathrm{B} € 0.63$ (Figure 3). In addition, this equilibrium model shows the biomass level (45Mt, $26 \%$ of $\mathrm{K}$ ) if current profits were to be maintained. In summary, this 286 figure indicates that allowing stocks to rebuild to the biomass consistent with MEY (108 Mt, $28763.5 \%$ of the unexploited biomass) would allow multiplying profits 20 fold. In other words, NA 288 fisheries are only generating $5 \%$ of their economic potential. It must be noted that the catch at MEY is estimated to be $12.66 \mathrm{Mt}$, only 25\% larger than the catch level in 2010.

290

291 ( \# Insert Table 3 \#)

292 (\# Insert Figures 3 and 4 \#)

293

294 Using the classic revenue-cost against fishing effort curve by Gordon (1954) (Figure 4), the 295 effort level that would lead to the economic maximization of North Atlantic fisheries is 296 estimated to be $47 \%$ of current effort. Thus, should fishing effort increase $10 \%$ above current levels, the NA fisheries would incur economic losses. Figure 4 also shows that assuming equilibrium conditions NA fisheries in 2010 were near the "Bioeconomic Equilibrium" (BE),

299 the point at which the fishery rents are dissipated as fishing costs are equal to the revenues from 300 fishing.

301

302 ( \# Insert Figure 5 \#)

303

304 The computations above are subject to uncertainties, and thus we added a level of stochasticity 305 to our model's input parameters, which indicated that the economic loss of North Atlantic 306 fisheries in 2010 ranged between $\mathrm{B} € 2.5$ and $\mathrm{B} € 32$ when all parameters were randomly 307 fluctuating with a $30 \%$ coefficient of variation (Figure 5). MSY and $\mathrm{Y}_{2010}$ are the most 
important sources of variation when estimating the economic losses of fisheries (Arnason, 2007;

309 Arnason et al., 2009) and Figure A.1 (Appendix). Besides, significant uncertainty was

310 propagated into estimates of stocks' carrying capacity ( $\mathrm{sdLog}=0.24)$. Therefore, specific

311 simulations investigating the impact of those three parameters were performed. Uncertainty in

312 estimation was moderately reduced by varying the three parameters through lognormal

313 distributions and generating random values with a uniform distribution with bounds $\pm 30 \%$ for

314 the others ('sim 2') or assuming them constant ('sim 3'). The simulations 'sim 3' and 'sim 4'

315 confirmed that these parameters generated the largest uncertainty on the final estimates of

316 economic loss. For 'sim 4', fixing MSY, K and $\mathrm{Y}_{2010}$ the variability of the loss estimate was

317 reduced significantly, ranging between $\mathrm{B} € 6$ and 19 with $95 \%$ confidence. The most important

318 result from these simulations is that the model is more sensitive to biological parameters and

319 therefore, biological parameterization is more important than economic parameterization.

320

321

322

323 We have provided an assessment of the economic losses due to the choices taken in the

324

325

326

327

328

329

330

331

332

333

334

335

336

337

338

339

340

341

342

343

\section{Discussion} management of North Atlantic fisheries. We have used methods previously implemented in the assessment of the economic losses of global fisheries (Arnason et al., 2009). Such a focus on the North Atlantic, in the context of the Euro_BASIN project, is motivated by the fact that its fisheries have a long history and economic importance, with significant catch-independent and dependent data sets, which are managed at different scales and with different degrees of success and failure.

The catch and value of North Atlantic fisheries have declined significantly in the last decade, partially due to management restricting catches (see below). The economic opportunity lost through the inefficient management of North Atlantic fisheries in 2010 was estimated to be $\mathrm{B} €$ 12.2. This echoes the results of a bioeconomic model built imposing strong assumptions on North Atlantic basin biological productivity and economic data of the fishing fleets operating in the area. Arnason et al 2009 estimated the global economic loss of marine fisheries due to overexploitation to be in a range of \$B 37-67. North Atlantic landings correspond to approximately $12 \%$ of global catches and the economic loss of NA fisheries represents $\sim 33 \%$ of global losses. This may be caused by the relative larger price of NA fisheries in comparison to other areas (Sumaila et al., 2007) and by the historical overfishing history of North Atlantic fisheries (FAO, 2012). For the North East Atlantic, Crilly and Esteban (2012) estimate that restoring fish stocks could deliver up to $£ 4.43$ billion per year in profits, approximately $41 \%$ of our estimate for the entire NA. 
345 Fisheries assessment provides information on the state of exploitation of marine resources and is 346 generally performed at stock level, a harvested unit which dynamics are driven by recruitment, 347 growth, natural mortality and fishing. Because of the limited number of fish stocks with stock 348 assessment data at the basin-scale, the catch based approached employed in this study allow us 349 to include a wider range of fish stocks. However, the catch based approach is based on the 350 assumption that catch reflects fish abundance and productivity. This principle is controversial, 351 especially when management interventions change through the history of catch time-series 352 (Pauly et al., 2013). However, catch-based methods are widely used to assess data-poor fisheries 353 and to produce large scale overviews of the state of fisheries (Fernandes et al., 2013; FAO, 354 2012; Lleonart \& Maynou, 2003; Pauly et al., 2003, Vasconcellos and Cochran, 2005). Data on 355 North Atlantic fisheries' are abundant, especially for ICES-assessed stocks. A specific problem 356 arises because data are not available at the basin scale, one of the challenges that the Euro357 BASIN project tries to address. Also, the proportion of assessed stocks in relation to total catch 358 differs across regions of the NA. For example, more than $90 \%$ of the North Sea catch (areas 359 IVa-c) corresponds to assessed stocks but in the Celtic Sea (VIIe-k) this number is less than $36040 \%$ (Gascuel et al., 2012). Using data that are only available from ICES statistical area may 361 thus provide a biased view of the status of fisheries in the NA basin. Besides, multi-species 362 MSY is less than the sum of single stocks', as demonstrated in this and other studies (Link et al., 363 2012; Sparholt \& Cook, 2009). Multi-species MSY could have been estimated with ecosystem 364 models as well. Fish species dynamics are regulated through trophodynamic interactions and 365 energetic fluxes across trophic levels (Pauly et al., 2000; Shin \& Cury, 2004), which are 366 reflected in the ecosystem's size spectra (Blanchard et al., 2009). For example, capelin, cod and 367 herring interact in the Barents Sea food web (Lindstrøm et al., 2009). However, these models 368 are relatively complex in relation to SPM (Coll et al., 2008). We favor the use of a simplified 369 aggregated surplus production model because these models can produce robust estimates of 370 multispecies environments (Sparholt \& Cook, 2009) allowing for comparison across areas 371 towards the practical implementation of the ecosystem-based fisheries management (Link et al., 372 2012). Also, this model provides a consistent platform to produce a macro scale assessment of 373 North Atlantic fisheries in combination with economic information.

374

375 We acknowledge that the use of an aggregated economic model requires significant 376 simplifications of complex ecological processes, and masks geographical differences in 377 ecosystems productivity and management efficiency. For example, let us look at two cod stocks 378 in the Irish and Icelandic Seas. Recent annual landings of Irish Sea cod have been lower than 5 $379 \mathrm{kt}$ with prospects for zero catch in 2013 and a stock which is currently outside biological limits 380 (ICES 2012a). In contrast, the Icelandic cod's TAC for 2012 was $177 \mathrm{k} \mathrm{t}$ and the stock is 
considered inside safe biological limits (ICES 2012b). The overall fishing effort recommended

382

383

384

385

386

387

388

389

390

391

392

393

394

395

396

397

398

399

400

401

402

403

404

405

406

407

408

409

410

411

412

413

414

415

416

417

to achieve MEY for NA fisheries would not be expected to be applied homogeneously to all stocks. The aggregative approach by-passes stock-specific responses and assumes that fishing effort reductions would have to focus those stocks catalogued as "overexploited" or "under overexploitation", and that benefits from adequate fishing management will be especially notable for the most productive areas of the North Atlantic.

Based on our analysis, North Atlantic fisheries remained within the estimated MSY range from 1964 to 2005. Then, total landings declined significantly and the estimation model associates this to overall overexploitation of NA resources. However, marine ecosystems are driven by multiple drivers that change over time; therefore, a constant historical MSY may not be realistic. The constant MSY estimated in the first part of this work is used for the subsequent economic assessment and should be considered with caution. Catch reductions can be caused by multiple factors, including overexploitation, environmental variability or implementation of catch restrictions. Overexploitation is defined by Hilborn and Stokes (2010) when catches are below $80 \%$ MSY, which equates to when declining yields are obtained with increased fishing effort (Schaefer 1954). The same is concluded from the biomass-catch diagram shown in Figure 3. When MSY is exceeded for extended periods and if fishing effort is maintained beyond the level corresponding to MSY, yield will decrease as the available biomass has fallen below the point at which MSY is achieved (50\% of its unexploited level, in this case). That is, biomass decreases with increasing catch until the point when biomass reductions will result in lower catches if fishing effort is not increased. In multispecies fisheries apparent MSY levels can be maintained by targeting previously undeveloped fisheries simultaneously with declining stocks. Using theoretical models, it has been shown that this feature can precede a sequential collapse of geographically distant fisheries (Merino et al., 2010; Merino et al., 2011).

This model does not consider environmental effects on the productivity of the NA basin. In reality, fish stocks, especially small pelagic fish (70-80\% of total NA catch), are highly vulnerable to environmental variability (Barange et al., 2009; Chavez et al., 2003; Fernandes et al., 2010; Hsieh et al., 2009). However, it is also evident that the impacts of particular environmental conditions differ between species. For example, Icelandic capelin catch averaged $1 \mathrm{Mt}$ from 1979 to 2002 (13\% the yields from ICES assessed stocks) when it started declining to $15 \mathrm{kt}$ in 2008. This decline is reflected in the overall NA trend and it could be caused by temperature changes (Carscadden et al., 2013 (In press)). However, other stocks such as herring (yielding $\sim 2 \mathrm{Mt}$ in the last decade) seem to be favored by current conditions and have recovered from overexploitation faster than expected (Nash et al., 2009), which could counterbalance the negative environmental impact on capelin on the basin scale trend. Another example is blue 
418 whiting whose catches have displayed a dramatic "boom and bust" dynamic over the past two 419 decades (ICES, 2011). Landings during the 1980s and early 1990s were typically between 500 420 and $1000 \mathrm{kt}$, but increased to $2400 \mathrm{kt}$ in 2004 as a result of a suite of good year classes. At this 421 point, blue whiting was the largest fishery in the North Atlantic, ahead of herring, and the third 422 largest marine capture fishery in the world (FAO, 2010). The subsequent decline of the fishery 423 has, however, proved to be equally dramatic (ICES, 2011). The alternation between warm and 424 cold regimes is associated to alternative species proliferation (Chavez et al., 2003), including 425 multidecadal regime shifts (Alheit et al., 2009). However, investigating each of the 426 environmental drivers affecting fish stocks in the North Atlantic in order to better estimate 427 individual MSYs would mean losing focus on the principal objective of this study and its scale.

A third factor resulting in catch reduction is management restriction. Generally, closures and 430 drastic catch limitations are the consequence of overexploiting resources and subsequent fishery 431 crises (Finlayson, 1994; Lazkano et al., 2012; Nøstbakken \& Bjørndal, 2003; Worm et al., 432 2009). Historically, fish stocks have collapsed due to a myriad of unfavorable environmental 433 conditions and excessive fishing pressure (Alheit et al., 2009; Chavez et al., 2003; Merino et al., 434 2013; Watson et al., 2006) and which triggered consequent catch restrictions (Worm et al., 435 2009). However, we would like to stress that, particularly the catch reduction in the last ten 436 years of the data series, should be attributed not only to historical overfishing but also to 437 management driven catch limitations. For example, under the EU framework, the Common 438 Fishery Policy and the Financial Instrument for Fisheries Guidance (FIFG) a remarkable 439 reduction of fishing boats has been accomplished (Fernandes and Cook 2013). In addition, since 4402005 emergency and recovery plans have applied under the EU adopted MSY framework 441 aiming to reduce fishing mortality towards achieving MSY for different stocks which is already 442 improving fisheries economic indicators (Cardinale et al., 2013). Furthermore, this approach is 443 followed by the International Council of the Exploration of the Sea (ICES) and other 444 international agreements (FAO, 2012). To sum up, some of the catch reductions reflected in the 445 basin scale trend (Figure 2) are aligned to the implementation of international efforts to restore 446 fish stocks and this can potentially bias the parameter estimation procedure used in this study by 447 estimating as economic loss what in reality may be a short term economic loss "invested" in 448 stocks recovery towards more profitable fisheries.

449

450 The parameters used in the bioeconomic model can be controversial too: For example, 451 classically, the supply-demand relation is considered as inverse: the lesser the catch, the higher 452 the price. However, the positive elasticity parameter used here was taken from Arnason et al 453 (2009) which aligns with a global perspective of the state of marine fisheries, as the "Fishing 454 down the food web" concept (Pauly et al 1997) does. However, this is expected to have low 
impact in our numeric results: The estimated catch increase when moving towards MEY would be small, so the expected price changes would be small too. A different matter is the potential impact of exogenous variables on North Atlantic fish demand and therefore, in the price equation used in this document. We do not consider the impact of aquaculture expansion on the price of wild fish nor the impact of imports that might act as less priced substitutes to North Atlantic fish. Both factors could presumably reduce the price of North Atlantic fish and therefore, the potential economic profit of North Atlantic fisheries would be reduced. Finally, our model is based on estimates of current profits of NA fisheries, estimated with value and fishing costs databases, and without considering the effects of subsidies. According to Sumaila et al (2012), 31\% of landed value in world fisheries is subsidized and therefore, the current profits for the fishing companies are presumably larger than the $\mathrm{B} € 0.63$ used to parameterize our bioeconomic model.

The implementation of ecosystem-based fisheries management (EBFM) requires the development of models to assess the economic performance of the fishing industry in combination with their impact upon marine ecosystems (Gascuel et al., 2012). The bioeconomic model used here was parameterized with a global estimate of NA ecosystems productivity and the sum of the economic performance indicators of the countries operating in its waters. In contrast to the biological part, the aggregation of the economic parameters was additive, we estimated the NA value of catch and net economic profits as the sum of the national estimates. The values shown in table 2 were obtained collating catch and value data from the Sea Around Us database and estimating the fleet specific costs of fishing using costs per tonne estimates from Lam et al (2011). Fishing costs and net profit values were also available from alternative reports. For example, the Annual Economic Report (AER) on the EU fishing fleet (JRC, 2012) provides estimates of many fishing indicators of EU countries. However, this report aggregates all EU countries fishing operations in waters beyond the NA. Using costs of fishing per tonne of catch in the NA allows for assigning the fishing costs only to the operations targeting North Atlantic fish. However, the cost structure provided in the AER is more detailed than in our approach. The net profit of EU fleets operating in the NA estimated in the AER is B€-0.236. Had this value been used as input to our bioeconomic model, our estimated loss would have been even larger. Additional sources of information on the economic performance of Russian, Norwegian, US and Canadian fleets (FAO, 2007; Kitts et al., 2010; NOAA, 2011) could improve the economic parameter estimation process. However, as seen in Figure 5, the most determinant set of parameters are those related to ecosystems productivity.

Our approach is based on deviations from biological and economic reference points. The economic loss pivots around the concept of Maximum Economic Yield, an equilibrium point 
492

493

494

495

496

497

498

499

500

501

502

503

504

505

506

507

508

509

510

511

512

513

514

515

516

517

518

519

520

521

522

523

524

525

526

527

528

where the net economic return from a fishery can be maximized sustainably, as assumed in previous studies (Arnason et al., 2009; Crilly \& Esteban, 2012; Sumaila et al., 2012). This reference point is estimated with a graphical procedure (Figure 3). Large benefits will be considered as unsustainable as they do not meet the parabola and; lower than the optimal will cross it twice, one for high levels of biomass and the other at biomass levels below that corresponding to MEY. It is important to note that the recovery of the stocks towards MEY biomass would not produce major changes in the overall catch from the NA. In 2010 10.8Mt of fish was landed whereas for the MEY total catch would be $12.66 \mathrm{Mt}$. Therefore, a catch increase of $26 \%$ would produce a net economic gain of $2000 \%$, but would require a $53 \%$ reduction in fishing effort. According to this, the economic benefit of restoring stocks would outweigh its potential food security implications (Garcia \& Rosenberg, 2010; Rice \& Garcia, 2011; Srinivasan et al., 2010). By reducing the fishing effort, costs would reduce linearly as revenues would increase potentially until the MSY peak. Then, further effort reductions would make revenues reduce too until its gradient equals fishing costs lines slope. As a result, a fishing effort reduction would produce a logarithmic increase in profits. Therefore, the profit increase would be more substantial at the initial stages of reduction. For example, if total fishing effort was reduced to $70 \%$ of current levels, total fish biomass (not each and every stock) would recover to MSY and profits would increase up to B€10.8 (1725\% more than in 2010). Therefore, accepting the hard transition of reducing the size of the industry to $47 \%$ of current level, it is important to note that moderate reductions would also produce large economic benefits as well as improving resource conservation significantly.

The reduction of fishing effort will have negative short term costs in the form of reduction of catch towards stocks recovery, loss of a notable number of current jobs provided by fisheries and costs to dismantle a number of the fishing boats currently operating in the North Atlantic. Therefore, it will require investments to reallocate fishermen in alternative activities, scrap fishing vessels and other compensations to the fishing industry. Crilly and Esteban (2012) and the work by Sumaila et al. (2012) demonstrate that after a short transition the benefits of restoring fish stocks outweighs the costs incurred and investments required to reduce fishing mortality. This conclusion holds notwithstanding the high uncertainty in estimates and the assumptions made to enable large scale assessments of governance (Cash \& Moser, 2000; Christensen \& Walters, 2004; Jennings et al., 2008; Wilbanks \& Kates, 1999). In addition, restoring fish stocks would avoid reducing the risk of fisheries collapses and its dramatic economic consequences. For example, the collapse of cod produced an increase of $30 \%$ of unemployment in some areas of Newfoundland and more than $\$ 3$ billion were spent to restructuring adjustments for workers in the fishing sector, among other social implications (Hamilton and Butler, 2001). However, it is also true that fishing mortality reductions haven't always produced the stocks' recovery predicted by fisheries assessment models. For example, a 
529

530

531

532

533

534

535

536

537

538

539

540

541

542

543

544

545

546

547

548

549

550

551

552

553

554

555

556

557

558

559

560

561

562

563

564

combination of environmental changes and fishing pressure are responsible of Atlantic cod populations failure to recover (Hilborn and Litzinger, 2009).

A single estimate of economic loss is intuitive but can be simplistic given the number of parameters involved in the computation. In order to add consistency to our results and to offset the uncertainty associated with our methods, four stochastic experiments were conducted with the bioeconomic model. The results of these experiments provide two conclusions: First, allowing as much as a $30 \%$ random variation in the input parameters, the estimated economic loss of North Atlantic fisheries is measured in billions of euro. Second, the model is particularly sensitive to three biological parameters: MSY, K and catch in the last year. Reducing the uncertainty on these parameters reduces the standard deviation of the estimates significantly. In contrast, fixing the other five parameters produces only moderate reductions of variability on the economic loss of fisheries. Therefore, we emphasize the relevance of adequate commercial and fishery independent data collection programs in order to improve the stock assessment process. Despite uncertainties on the current scale of North Atlantic basin productivity, we conclude that an overall fishing effort reduction is recommended, with not only ecological benefits but significant and demonstrable economic consequences.

To conclude, our analysis supports the work conducted under the Euro-BASIN project by providing a basin-scale framework for the economic analysis of the efficiency of North Atlnatic fisheries management. In the future this analysis needs to take into consideration the way European fisheries management, in particular, is evolving. The reform of the European Common Fisheries Policy identifies MSY as a management target, consistent with our analysis. It also highlights the need to implement a discard ban, which should come hand in hand with the needed improyement in the monitoring and reporting of fishing activities. While our analysis is conducted at the basin scale, regionalization of management is a process that would need to be considered in future monitoring programs and modeling approaches. Significantly, the CFP reform also identifies the need to collect environmental, social and economic data and use these as criteria to allocate fishing rights. Future Euro-BASIN initiatives would have to consider the above in developing their workprogramme, as well as approaches to better understand market price formation (exports and competition with products from other areas) and how to influence consumer demand for species that traditionally have been less preferred.

\section{Acknowledgments}


This research was supported by European Union seventh framework programme through the

Scott for the valuable comments in the preparation of this manuscript.

569

570

\section{Appendix}

571

572

Table A1. Necessary transformations to run the bioeconomic model using the parameters shown

573 in Table 3 (Arnason, 2007; Arnason et al., 2009; Gordon, 1954; Schaefer, 1954).

574

$575 \quad\{$ Insert Table A1 $\}$

576

577

Figure A1. Sensitivity analysis of the economic loss in 2010 for different parameters.

578

579

\{Insert Figure A1\}

580 References

581

582

583

584

585

586

587

588

589

590

591

592

593

594

595

596

597

- Alheit, J., Roy, C., Kifani, S., 2009. Decada-scale variability in populations. In D. Checkley, J. Alheit, Y. Oozeki, C. Roy (Eds.), Climate Change and Small Pelagic Fish Stocks (p. 382): Cambridge University Press.

- Allison, E.H., Perry, A.L., Badjeck, M.C., Adger, W.N., Brown, K., Conway, D., Halls, A.S., Pilling, G., Reynolds, J.D., Andrew, L.N., Dulvy, N., 2009. Vulnerability of national economies to the impacts of climate change on fisheries. Fish and Fisheries, 10, 173-196.

- Arnason, R., 2007. Loss of economic rents in the global fishery. XVIIIth Annual EAFE Conference. Reykjavik, Iceland: www.eafe-fish.eu.

- Arnason, R., Kelleher, K., Willman, R., 2009. The Sunken Billions: The economic justification for fisheries reform. Agriculture and rural development (p. 100): The World Bank and Food and Agriculture Organization.

- Barange, M., Bernal, M., Cercole, M.C., Cubillos, L., Cunningham, C.L., Daskalov, G.M., De Oliveira, J.A.A., Dickey-Collas, M., Hill, K., Jacobson, L., Køster, F.W., Masse, J., Nishida, H., Niquen, M., Oozeki, Y., Palomera, I., Saccardo, S.A., Santojanni, A., Serra, R., Somarakis, S., Stratoudakis, Y., van der Lingen, C.D., Uriarte, A., Yatsu, A., 2009. Current trends in the Assessment and Management of Small Pelagic Fish Stocks. In D. Checkley, J. Alheit, Y. Oozeki, C. Roy (Eds.), Climate Change and Small Pelagic Fish Stocks (p. 382): Cambridge University Press.

- Beaugrand, G., Reid, P.C., Ibañez, F., Lindley, J.A., Edwards, M., 2002. Reorganization of North Atlantic marine copepod biodiversity and climate. Science, 296, 1692-1694.

- Blanchard, J., Jennings, S., Holmes, R., Harle, J., Merino, G., Allen, I., Holt, J., Dulvy, N., Barange, M., 2012. Potential consequences of climate change for primary production and fish production in large marine ecosystems. Philosophical Transactions of the Royal Society B, 367, 2979-2989. 
- Blanchard, J., Jennings, S., Law, R., Castle, M.D., McCloghrie, D., Rochet, M.J., Benoît, E., 2009. How does abundance scale with body size in coupled size-structured food webs? Journal of Animal Ecology, 78, 270-280.

- Branch, T.A., Jensen, O.P., Ricard, D., Ye, Y., Hilborn, R., 2011. Contrasting global trends in marine fishery status obtained from catches and stock assessments. Conservation Biology, 25, 777-786.

Cardinale, M., Dorner, H., Abella, O., Andersen, J.L., Casey, J., Doring, R., Kirkegaard, E., Motova, A., Anderson, J., Simmonds, E.J., Stransky, C., 2013. Rebuilding EU fish stocks and fisheries, a process under way? Marine Policy, 39, 43-52.

- Carscadden, J.E., Gjøsæter, H., Vilhjálmsson, H., 2013 (In press). A comparison of recent changes in distribution of capelin (Mallossus villotus) in the Barents Sea, around Iceland and in the Northwest Atlantic. Progress In Oceanography.

- Cash, D.W., Moser, S.C., 2000. Linking global and local scales: designing dynamic assessment and management processes. Global Environmental Change, 10, 109-120.

- Coll, M., Libralato, S., Tudela, S., Palomera, I., Pranovi, F., 2008. Ecosystem Overfishing in the Ocean. PLoS ONE, 3, e3881.

- Crilly, R., Esteban, A., 2012. No catch investment: Investing to restore European fish stocks. In N.E. Foundation (Ed.). London, UK.

- Cury, P.M., Shin, Y.-J., Planque, B., Durant, J.M., Fromentin, J.M., Kramer-Schadt, S., Stenseth, N.C., Travers, M., Grimm, V., 2008. Ecosystem oceanography for global change fisheries. Trends in Ecology and Evolution, 23, 338-346.

- Chavez, F.P., Ryan, J., Lluch-Cota, S.E., Niquen C, M., 2003. From anchovies to sardines and back: multidecadal change in the Pacific ocean. Science, 299, 217-221.

- Christensen, V., Walters, C.J., 2004. Trade-offs in ecosystem scale optimization of fisheries managament policies. Bulletin of Marine Science, 74, 549-562.

- European Union. 2012. Communication from the Commission to the Council concerning a consultation on Fishing Opportunities for 2013. COM(2012) 278 final, 17 pp.

- FAO, FISHSTAT Statistical collections. FAO.

- FAO, 2007. National fishery sector overview: The Russian Federation. (p. 17).

- FAO, 2010. Statistics and Information Service of the Fisheries and Aquaculture Department. FAO yearbook. Fishery and Aquaculture Statistics 2008. Rome, Italia. $72 \mathrm{p}$.

- FAO, 2012. The State of World Fisheries and Aquaculture. In FAO (Ed.). Rome.

- Fernandes J.A., Cheung W.W.L., Jennings S., Butenschön M., de Mora L., Frölicher T.L., Barange M., Grant A., 2013. Modelling the effects of climate change on the distribution and production of marine fishes: accounting for trophic interactions in a dynamic bioclimate envelope model. Global Change Biology 19(8), 2596-2607.

- Fernandes, P.G., Cook, R.M., 2013. Reversal of fish stock decline in the Northeast Atlantic. Current Biology, 23(15), 1432-1437.

- Fernandes J.A., Irigoien X., Goikoetxea N., Lozano J.A., Inza I., Pérez A, Bode A., 2010. Fish recruitment prediction, using robust supervised classification methods. Ecological Modelling, 221(2), 338-352.

- Finlayson, A.C., 1994. Fishing for truth: A sociological analysis of northern cod stock assessments from 1977-1990. St. John's, Newfoundland, Canada: Memorial University of Newfoundland. 
661

662

663

664

665

666

667

668

669

670

671

672

673

674

675

676

677

678

679

680

681

682

683

684

685

686

687

688

689

690

691

692

693

694

695

696

697

698

- Garcia, S.M., 2009. Rising to depletion? Towards a dialogue on the state of national marine fisheries. Preliminary report. In T.W. Bank (Ed.), Global Program on Fisheries (PROFISH) (p. 65).

- Garcia, S.M., Rosenberg, A.A., 2010. Food security and marine capture fisheries: characteristics, trends, drivers and future perspectives. Philosophical Transactions of the Royal Society B, 365, 2869-2880.

- Gascuel, D., Merino, G., Döring, R., Druon, J.N., Goti, L., Guénette, S., Macher, C., Soma, K., Travers-Trolet, M., Mackinson, S., 2012. Towards the implementation of an integrated ecosystem fleet-based management of European fisheries. Marine Policy, 36, 1022-1032.

- Gordon, H.S., 1954. The economic theory of a common-property resource: the fishery. Journal of Political Economy, 62, 124-142.

- Guillen, J., Macher, C., Merzéréaud, M., Bertignac, M., Fifas, S., Guyader, O., 2013. Estimating MSY and MEY in multi-species and multi-fleet fisheries, consequences and limits: an application to the Bay of Biscay mixed fishery. Marine Policy, 40, 64-74.

- Hamilton, L.C., Bulter, M.J., (2001) Outport adaptations: social indicators through Newfoundland's cod crisis. Research in Human Ecology, 8(2), 1-11.

- Hilborn, R., Stokes, K., 2010. Defining overfished stocks: Have we lost the plot? Fisheries, 35, 113-120.

- Hsieh, C.-H., Kim, H.J., Watson, W., Di Lorenzo, E., Sugihara, G., 2009. Climate driven changes in abundance and distribution of larvae of oceanic fishes in the southern California region. Global Change Biology, 15, 2137-2152.

- ICES, 2011. Report of the Working Group on Widely Distributed Stocks (WGWIDE). ICES CM 2011/ACOM:15. 624 pp.

- ICES. 2012b. Report of the ICES Advisory Committee 2012. ICES Advice, 2012. Book $5.459 \mathrm{pp}$.

- ICES. 2012b. Report of the ICES Advisory Committee 2012. ICES Advice, 2012. Book 2. $114 \mathrm{pp}$.

- Jennings, S., Mélin, F., Blanchard, J.L., Forster, R.M., Dulvy, N.K., Wilson, R.W., 2008. Global-scale predictions of community and ecosystem properties from simple ecological theory. Proceedings of the Royal Society B: Biological Sciences, 275, 13751383.

- JRC, 2012. The 2011 Annual Economic Report on the EU fishing fleet. In J. Anderson, J. Guillen, J. Virtanen (Eds.), Scientific, technical and economic committee for fisheries.

- Kitts, A., Bing-Sawyer, E., Walden, J., Demarest, C., McPherson, M., Christman, P., Steinback, S., Olson, J., Clay, P., 2010. Performance of the Northeast multispecies (groundfish) fishery. In N.N.M.F. Service (Ed.). Woods Hole, MA.

- Lam, V.W.Y., Sumaila, R.U., Dyck, A., Pauly, D., Watson, R., 2011. Construction and first applications of a global cost of fishing database. ICES Journal of Marine Science, 68, 1996-2004.

- Lazkano, I., Nøstbakken, L., Prellezo, R., 2012. Past and future management of a collapsed fishery: The bay of Biscay anchovy. Natural Resource Modeling.

- Lindstrøm, U., Smoutb, S., Howellc, D., Bogstadc, B., 2009. Modelling multi-species interactions in the Barents Sea ecosystem with special emphasis on minke whales and their interactions with cod, herring and capelin. Deep-Sea Research Part II: Topical Studies in Oceanography, 56, 2068-2079. 
703

704

705

706

707

708

709

710

711

712

713

714

715

716

717

718

719

720

721

722

723

724

725

726

727

728

729

730

731

732

733

734

735

736

737

738

739

740

741

742

743

- Link, J.S., 2009. Ecosystem-Based Fisheries Management: Confronting Tradeoffs. New York: Cambridge University Press.

- Link, J.S., Gaichas, S., Miller, T.J., Essington, T., Bundy, A., Boldt, J., Drinkwater, K., Moksness, E., 2012. Synthesizing lessons learned from comparing fisheries production in 13 northern hemisphere ecosystems: emergent fundamental features. Marine Ecology Progress Series, 459, 293-302.

- Lleonart, J., Maynou, F., 2003. Fish stock assessments in the Mediterranean: state of the art. Scientia Marina, 67 (Suppl. 1), 37-49.

- Marshall, J., Kushnir, Y., Battisti, D., Chang, P., Czaja, A., Dickson, R., Hurrell, J., McCartney, M., Saravanan, R., Visbeck, M., 2001. North Atlantic climate variability: phenomena, impacts and mechanisms. International Journal of Climatology, 21, 18631898.

- Martell, S., Froese, R., 2010. A simple method for estimating MSY from catch and resilience. Fish and Fisheries.

- Merino, G., Barange, M., Mullon, C., Rodwell, L., 2010. Impacts of global environmental change and aquaculture expansion on marine ecosystems. Global Environmental Change, 20, 586-596.

- Merino, G., Barange, M., Rodwell, L., Mullon, C., 2011. Modelling the sequential geographical exploitation and potential collapse collapse of marine fisheries through economic globalization, climate change and management alternatives. Scientia Marina, 75, 779-790.

- Merino, G., Barange, M., Blanchard, J., Harle, J., Holmes, R., Allen, I., Allison, E.H., Badjeck, M.C., Dulvy, N., Holt, J., Jennings, S., Mullon, C., Rodwell, L., 2012. Can marine fisheries and aquaculture meet fish demand from a growing human population in a changing climate? Global Environmental Change, http://dx.doi.org/10.1016/j.gloenycha.2012.03.003.

- Merino, G., Barange, M., Mullon, C., 2013. Role of reduction fisheries in the world fishmeal production. In K. Ganias (Ed.), Biology and ecology of anchovies and sardines. Enfield, New Hampshire, USA: Science Publishers.

- Mueter, F.J., Megrey, B.A., 2006. Using multi-species surplus production models to estimate ecosystem-level maximum sustainable yields. Fisheries Research, 81, 189201.

- Nash, J.F., Dickey-Collas, M., Kell, L.T., 2009. Stock and recruitment in North Sea herring (Clupea harengus); compensation and depensation in the population dynamics. Fisheries Research, 95, 88-97.

- NOAA, 2011. Fisheries Economics of the United States 2009. In U.D.o. Commerce (Ed.), Vol. NMFS-F/SPO-118: National Oceanic and Atmospheric Administration.

- Nøstbakken, L., Bjørndal, T., 2003. Supply functions for North Sea herring. Marine Resource Economics, 18, 345-361.

- Parsons, L.S., Lear, W.H., 2001. Climate variability and marine ecosystem impacts: a North Atlantic perspective. Progress In Oceanography, 49, 167-188.

- Pauly, D., Alder, J., Bennett, E., Christensen, V., Tyedmers, P., Watson, R., 2003. The future for fisheries. Science, 302, 1359-1361.

- Pauly, D., Christensen, V., Dalsgaard, J., Froese, R., Torres, Jr. F. 1997. Fishing down marine food webs. Science, 278, 860-863. 
- Pauly, D., Christensen, V., Guenette, S., Pitcher, T.J., Sumaila, U.R., Walters, C.J., Watson, R., Zeller, D., 2002. Towards sustainability in world fisheries. Nature, 418, 689-695.

- Pauly, D., Christensen, V., Walters, C.J., 2000. Ecopath, Ecosim, and Ecospace as tools for evaluating ecosystem impact of fisheries. ICES Journal of Marine Science, 57, 697706.

- Pauly, D., Hilborn, R., Branch, T.A., 2013. Fisheries: Does catch reflect abundance? Nature, 694, 303-306.

- Rice, J.C., Garcia, S.M., 2011. Fisheries, food security, climate change and biodiversity: characteristics of the sector and perspectives of emerging issues. ICES Journal of Marine Science, 68(6), 1343-1353.

- Schaefer, M., 1954. Some aspects of the dynamics of populations important to the management of the commercial Marine fisheries. Bulletin of the Inter-American Tropical Tuna Commission, 1, 27-56.

- Seijo, J.C., Defeo, O., Salas, S., 1998. Fisheries bioeconomics. Theory, modelling and management. Rome.

- Shin, Y.-J., Bundy, A., Shannon, L.J., Blanchard, J.L., Chuenpagdee, R., Coll, M., Knight, B., Lynam, C., Piet, G.J., Richardson, A.J., Group, a.t.I.W., 2012. Global in scope and regionally rich: an Indiseas workshop helps shape the future of marine ecosystem indicators. Reviews in Fish Biology and Fisheries, 22, 835-845.

- Shin, Y.-J., Cury, P.M., 2004. Using an individual-based model of fish assemblages to study the response of size spectra to changes in fishing. Canadian Journal of Fisheries and Aquatic Sciences, 61, 414-431.

- Shin, Y.-J., Rochet, M.-J., Jennings, S., Field, J.G., Gislason, H., 2005. Using sizebased indicators to evaluate the ecosystem effects of fishing. ICES Journal of Marine Science, 62, 384-396.

- Sparholt, H., Cook, R., 2009. Sustainable exploitation of temperate fish stocks. Biology Letters.

- Srinivasan, U.T., Cheung, W.W.L., Watson, R., Sumaila, R.U., 2010. Food security implications of global marine catch losses due to overfishing. Journal of Bioeconomics, $12,183-200$.

- Sumaila, R.U., Cheung, W.W.L., Dyck, A., Gueye, K., Huang, L., Lam, V., Pauly, D., Srinivasan, T., Swartz, W., Watson, R., Zeller, D., 2012. Benefits of rebuilding global marine fishereis outweigh costs. PLoS ONE, 7, e40542.

- Sumaila, R.U., Marsden, A.D, Watson, R., Pauly, D., 2007. A Global ex-vessel fish price database: Construction and Applications. Journal of Bioeconomics, 9, 29-51.

Trenkel, V.M., Huse, G., MacKenzie, B.R., Alvarez, P., Arrizabalaga, H., Castonguay, M., Goñi, N., Grégoire, F., Hátun, H., Jansen, T., Jacobsen, J.A., Lehodey, P., Lutcavage, M., Mariani, P., Melvin, G.G., Neilson, J.D., Nøttestad, L., Óskarsson, G.J., Payne, M.R., Richardson, D.E., Senina, I., Speirs, D.C., 2013 (In press in this issue). Comparative ecology of widely distributed pelagic fish species in the North Atlantic: implications for modelling climate and fisheries impacts. Progress in Oceanography.

- Vasconcellos, M., Cochrane, K., 2005. Overview of world status data-limited fisheries: inferences from landings statistics, In: Fisheries assessment and management in datalimited situations. Proceedings; Lowell Wakefield Symposium, 21, Anchorage, AK (USA), 22-25 Oct 2003. Kruse, G.H. (ed.) Gallucci, V.F. (ed.) Hay, D.E. (ed.) Perry, R.I. (ed.) Peterman, R.M. (ed.) Shirley, T.C. (ed.) Spencer, P.D. (ed.) Wilson, B. (ed.) 
Woodby, D. (ed.) / Alaska Univ., Fairbanks (USA). Alaska Sea Grant College Program, 2005, p. 1-20.

- Watson, R., Alder, J., Pauly, D., 2006. Fisheries for forage fish, 1950 to the present. In J. Alder, D. Pauly (Eds.), On the multiple uses of forage fish: from ecosystems to markets (pp. 1-20).

- Wilbanks, T.J., Kates, R., 1999. Global change in local places: how scale matters. Climatic Change, 43, 601-628.

798

799

- Wiebe, P.H., Harris, R.P., St. John, M.A., Werner, F.E., de Young, B., 2009. P.P.E. (Eds.), 2009. BASIN: Basin-scale Analysis, Synthesis and Integration. Science Plan and Implementation Strategy.

- Worm, B., Hilborn, R., Baum, J.K., Branch, T.A., Collie, J.S., Costello, C., Fogarty, M.J., Fulton, E.A., Hutchings, J.A., Jennings, S., Jensen, O.P., Lotze, H.K., Mace, P.M., McClanahan, T.R., Minto, C., Palumbi, S.R., Parma, A.M., Ricard, D., Rosenberg, 


\section{Figure captions}

Figure 1. Maximum Sustainable Yield estimates for the stocks assessed by ICES at different aggregation levels. The aggregation level is the number of units considered: 59 stocks, 18 species, 2 habitats and 1 for all the ICES stocks as a single fishery. Boxes show the geometric mean of the estimate, 0.25 and 0.75 quantiles. The intervals limit the estimate to a $99.5 \%$ confidence (see text).

Figure 2. Top: Historical landings of North Atlantic fisheries according to FAO and estimated corresponding MSY. Below: Density distribution of annual total landings and distribution of plausible total MSY values using the approach by Martell and Froese (2013).

Figure 3. Graphical estimation of North Atlantic fisheries Maximum Economic Yield. The crossing point between different potential profit trajectories (iso_ $\Psi$ ) and the biomass-catch equilibrium curve determines the catch and biomass level that will lead to MEY. The MEY for North Atlantic fisheries is $\mathrm{B} € 12.85$. The $i s o_{-} \Psi=0.63 \mathrm{~B} €$ corresponds to profits in 2010.

Figure 4. Gordon-Schaefer's model equilibrium for North Atlantic fisheries. Current (2010) and economically optimum fishing efforts indicated with dotted lines. Net profits are calculated as the difference between value of catch and costs of fishing. MEY is the Maximum Economic Yield, i.e. the maximum difference between value of catch and costs of fishing.

Figure 5. Results of stochastic estimates of the economic loss of North Atlantic fisheries in 2010: 'sim 1' random fluctuation $( \pm 30 \%)$ of the parameters of the bioeconomic model (see table 3); 'sim 2' log-normally distributed MSY, $K$ and $\mathrm{Y}_{2010}$ and random fluctuation for the others $( \pm 30 \%)$; ' $\operatorname{sim} 3$ ' same as previous but with other parameters kept constant at values shown in table 3; 'sim 4' MSY, K and $\mathrm{Y}_{2010}$ constant and random fluctuation for the others $( \pm 30 \%)$.

Figure A1. Sensitivity analysis of the economic loss in 2010 for different parameters. 


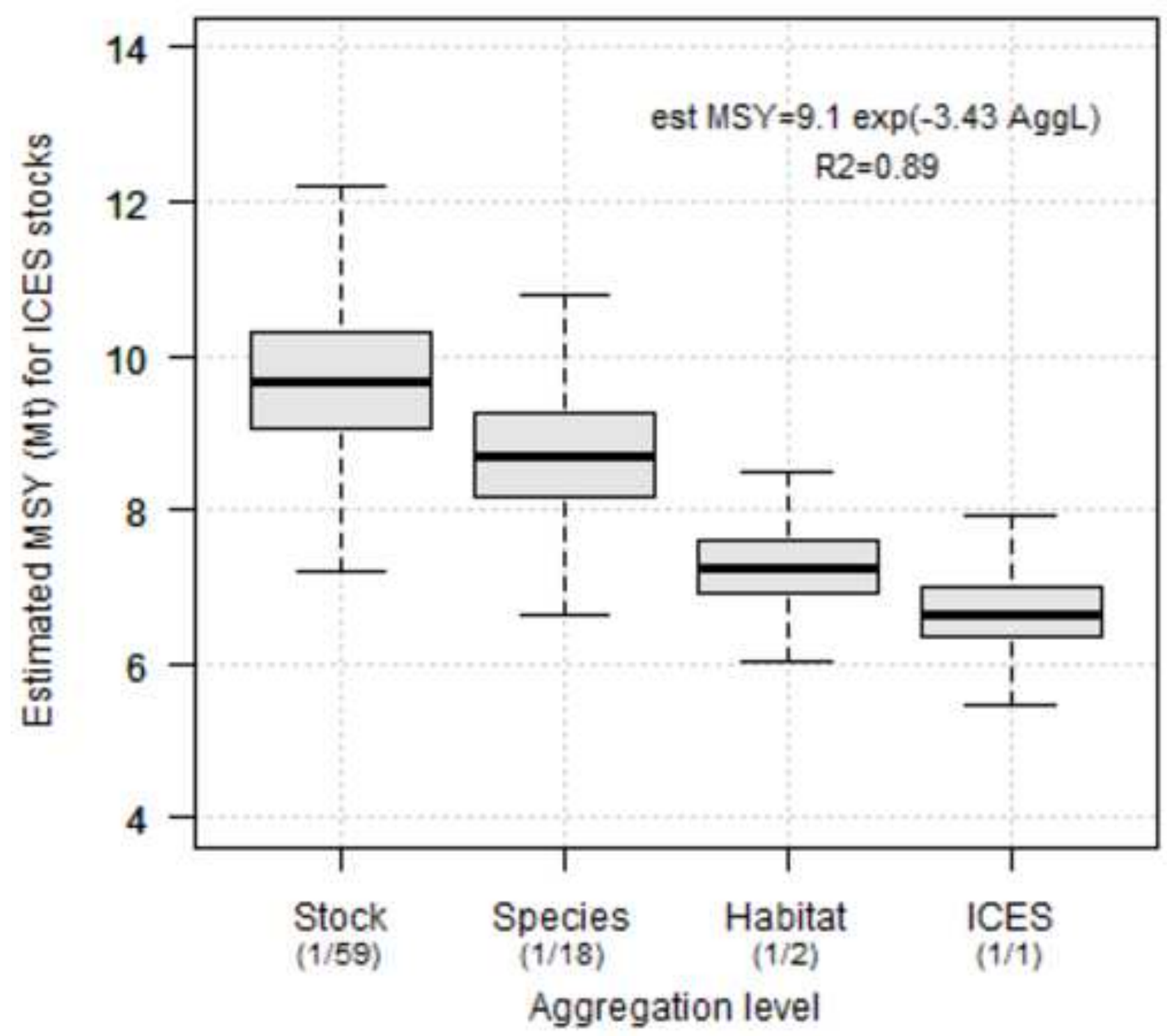


North Atlantic landings (FAO) and MSY estimates
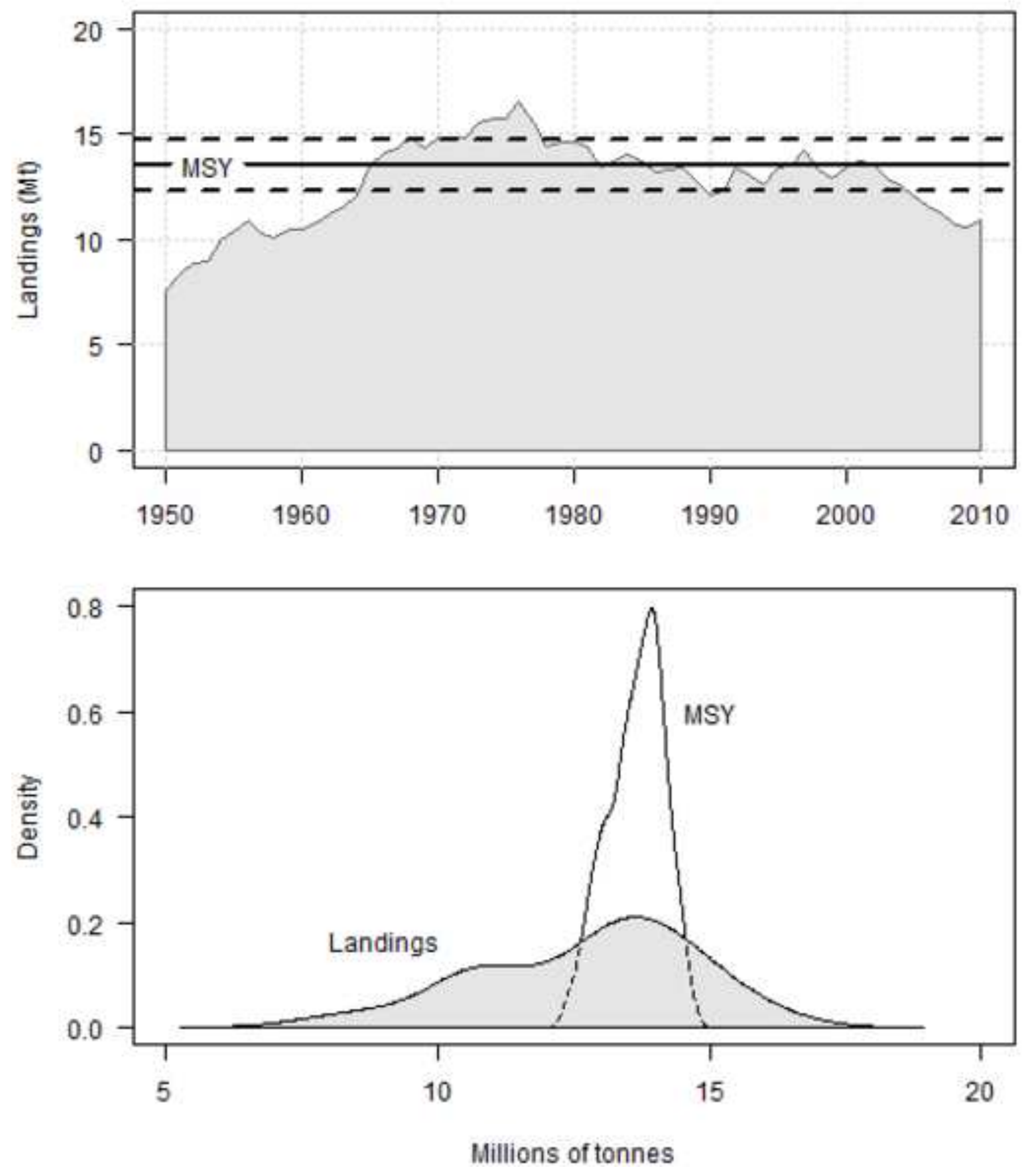


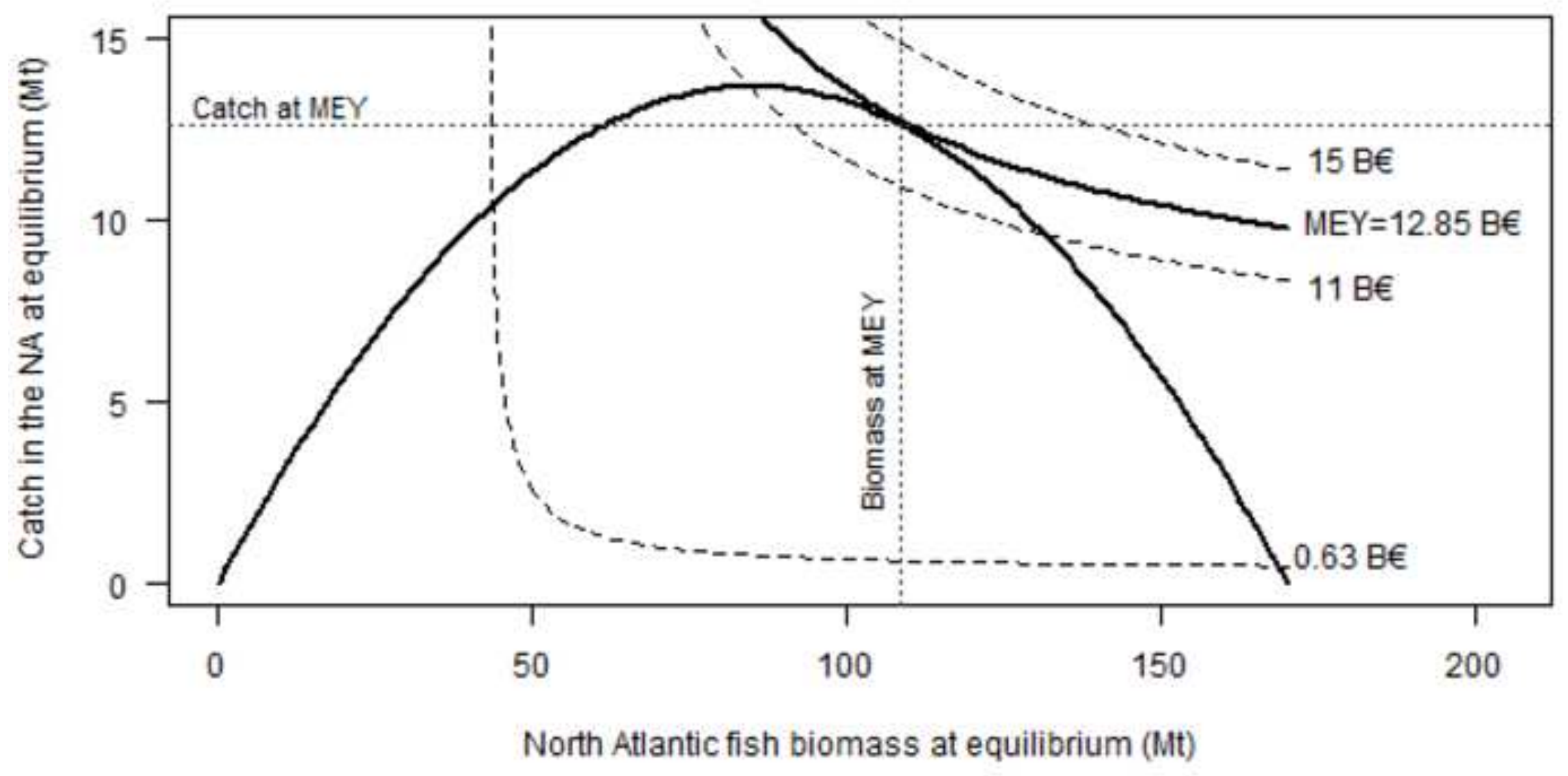




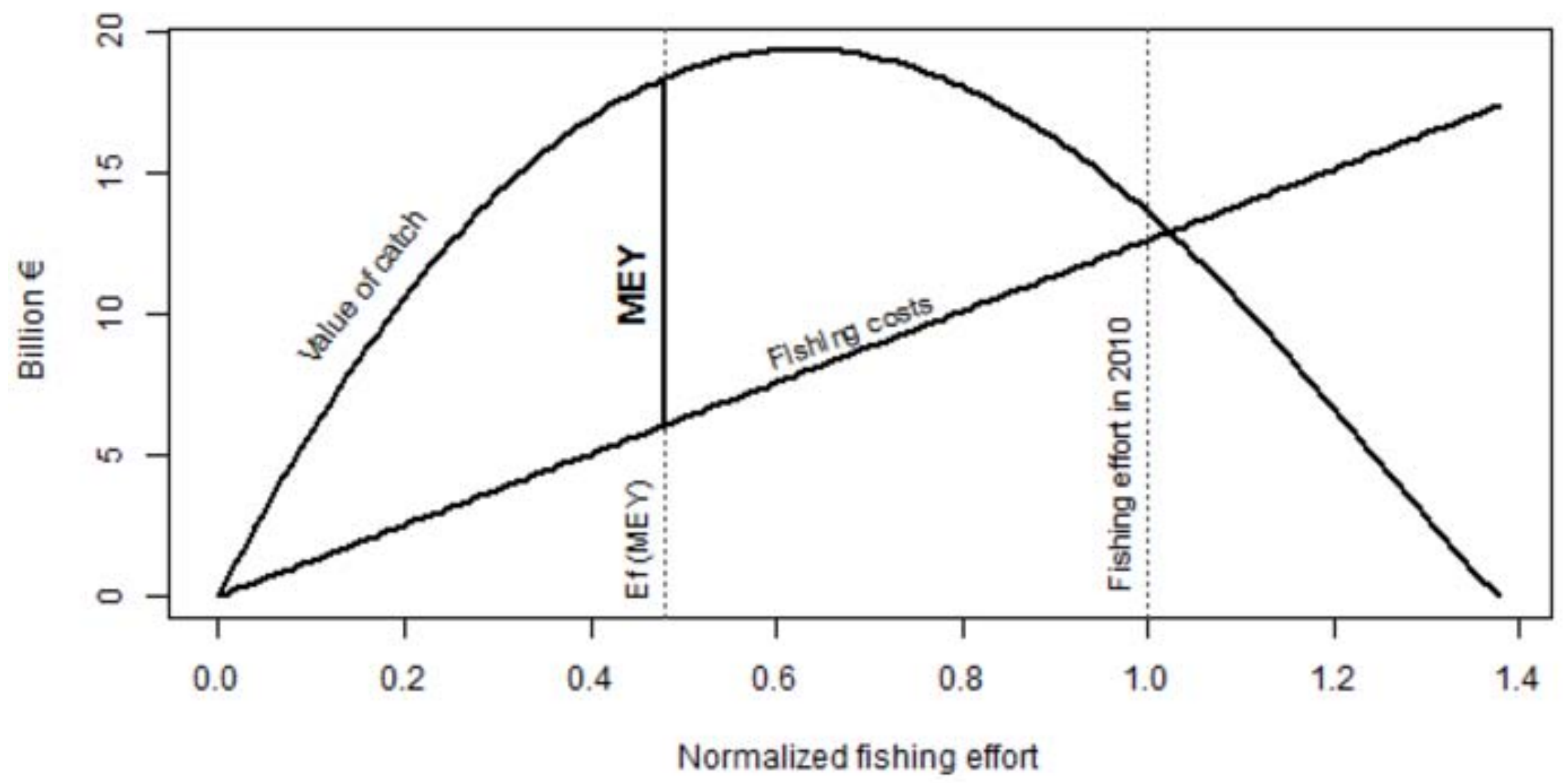




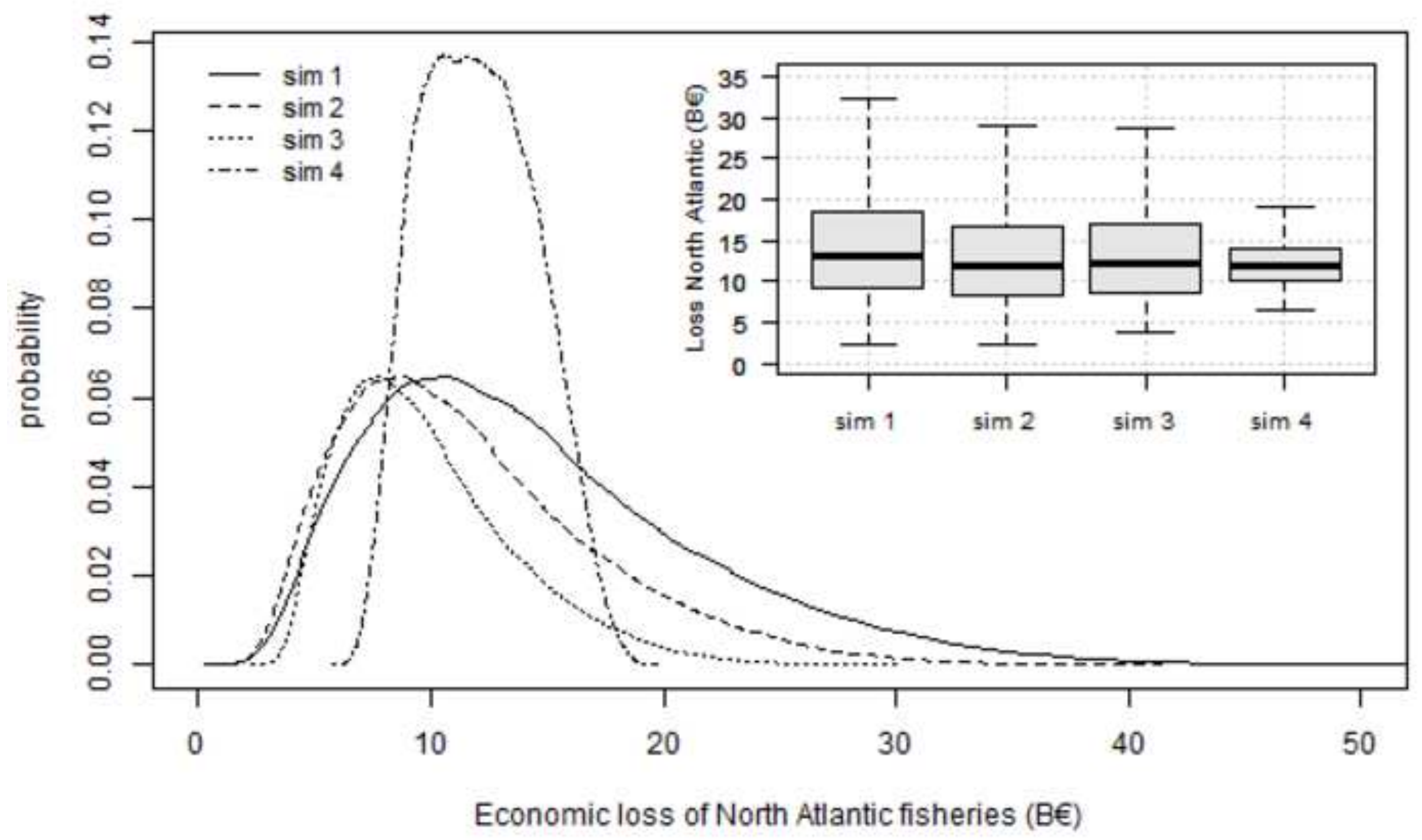




\section{Sensitivity to input paramaters}

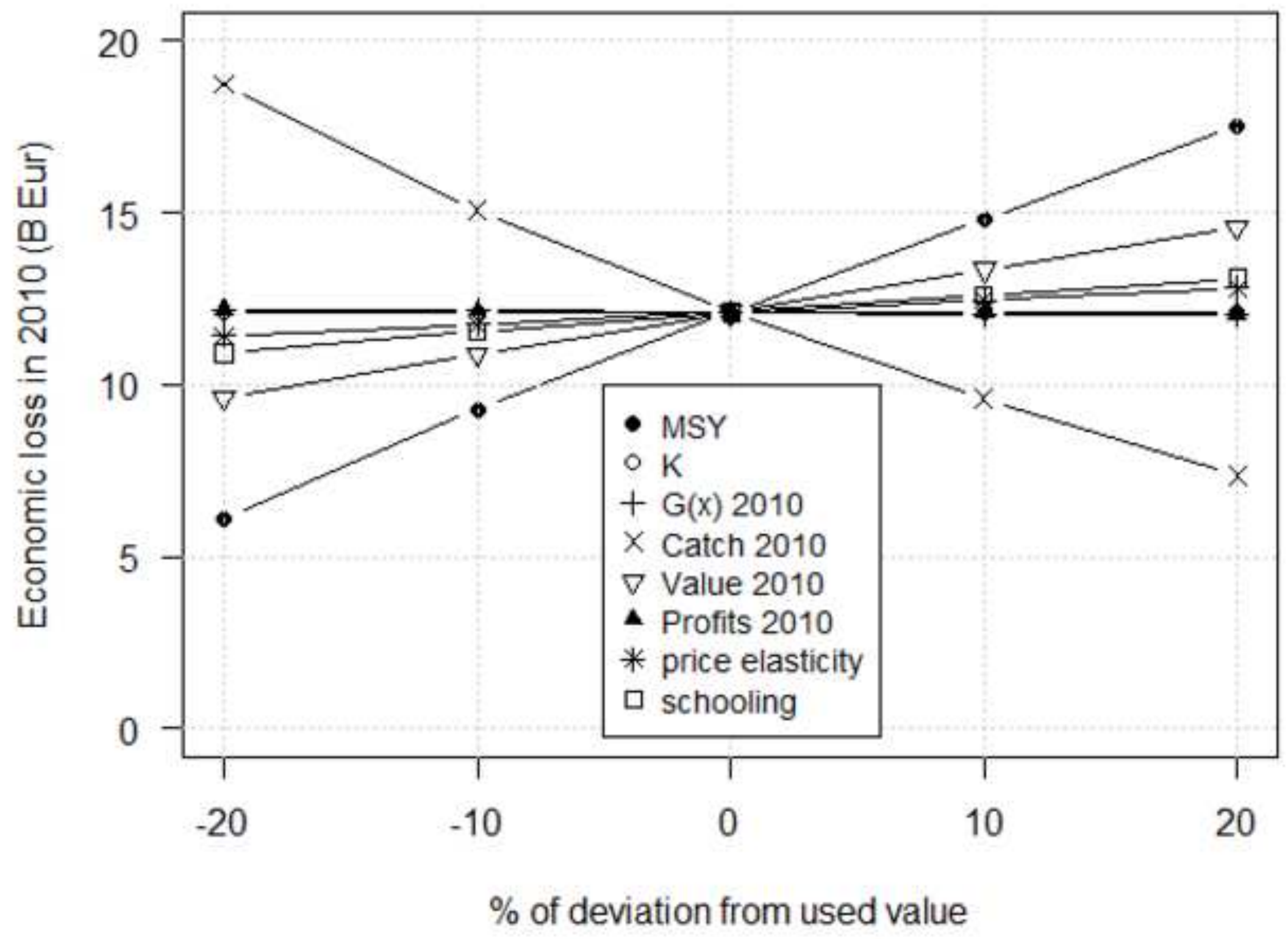


Tables

841

Table 1. Estimated Maximum Sustainable Yield for different levels of aggregation of ICESstocks.

\begin{tabular}{|c|c|c|c|}
\hline $\begin{array}{c}\text { Total } \\
M S Y(\text { Mean Mt, sdLog) }\end{array}$ & $\begin{array}{c}\text { Habitat } \\
\text { MSY (Mean Mt, sdLog) }\end{array}$ & $\begin{array}{c}\text { Species } \\
M S Y(\text { Mean kt, sdLog) }\end{array}$ & $\begin{array}{c}\text { ICES-Stock } \\
\text { MSY (Mean kt, sdLog) }\end{array}$ \\
\hline \multirow{37}{*}{$\begin{array}{c}\text { ICES } \\
(6.68,0.07)\end{array}$} & \multirow{33}{*}{ Demersal2.26, 0.03) } & \multirow{9}{*}{$\begin{array}{c}\text { Cod } \\
(1364.61,0.03)\end{array}$} & cod-2224 (38.91, 0.09) \\
\hline & & & cod-2532 $(181.77,0.06)$ \\
\hline & & & cod-347d $(256.87,0.05)$ \\
\hline & & & cod-arct $(737.22,0.05)$ \\
\hline & & & cod-coas $(59.71,0.1)$ \\
\hline & & & cod-farp $(24.48,0.05)$ \\
\hline & & & cod-iceg $(374.87,0.06)$ \\
\hline & & & cod-iris $(8.72,0.07)$ \\
\hline & & & cod-scow $(16.41,0.12)$ \\
\hline & & $\begin{array}{c}\text { Greenland halibut } \\
(20.38,0.20)\end{array}$ & ghl-arct $(20.16,0.2)$ \\
\hline & & \multirow{7}{*}{$\begin{array}{c}\text { Haddock } \\
(419.40,0.04)\end{array}$} & had-34 $(281.57,0.07)$ \\
\hline & & & had-7b-k $(12.61,0.18)$ \\
\hline & & & had-arct $(164.18,0.13)$ \\
\hline & & & had-faro $(18.11,0.06)$ \\
\hline & & & had-iceg $(81.20,0.18)$ \\
\hline & & & had-rock $(4.67,0.12)$ \\
\hline & & & had-scow $(23.36,0.07)$ \\
\hline & & $\begin{array}{c}\text { Megrim } \\
(1.23,0.11) \\
\end{array}$ & mgb-8c9a $(1.23,0.11)$ \\
\hline & & $\begin{array}{l}\text { Anglerfish } \\
(0.46,0.14)\end{array}$ & $\mathrm{mgw}-8 \mathrm{c} 9 \mathrm{a}(0.46,0.14)$ \\
\hline & & \multirow{2}{*}{$\begin{array}{c}\text { Nephrops } \\
(5.15,0.09)\end{array}$} & nep-8ab $(5.68,0.11)$ \\
\hline & & & nop-34 $(0.18,0.13)$ \\
\hline & & \multirow{5}{*}{$\begin{array}{c}\text { Plaice } \\
(122.48,0.04)\end{array}$} & ple-celt $(1.18,0.07)$ \\
\hline & & & ple-eche $(4.32,0.07)$ \\
\hline & & & ple-echw $(1.68,0.08)$ \\
\hline & & & ple-iris $(3.38,0.05)$ \\
\hline & & & ple-nsea $(114.97,0.04)$ \\
\hline & & \multirow{7}{*}{$\begin{array}{c}\text { Sole } \\
(31.93,0.06)\end{array}$} & sol-bisc $(5.27,0.08)$ \\
\hline & & & sol-celt $(1.12,0.06)$ \\
\hline & & & sol-eche $(4.73,0.11)$ \\
\hline & & & sol-echw $(0.97,0.05)$ \\
\hline & & & sol-iris $(1.40,0.08)$ \\
\hline & & & sol-kask $(0.77,0.09)$ \\
\hline & & & sol-nsea $(21.4,0.04)$ \\
\hline & \multirow{4}{*}{$\begin{array}{c}\text { Pelagic } \\
\text { (4.99 Mt, 0.08) }\end{array}$} & $\begin{array}{c}\text { Capelin } \\
(867.50,0.07) \\
\end{array}$ & cap-icel $(866.05,0.07)$ \\
\hline & & \multirow{3}{*}{$\begin{array}{c}\text { Herring } \\
(2028.94,0.13)\end{array}$} & her-2532-gor $(245.28,0.09)$ \\
\hline & & & her-30 $(61.63,0.15)$ \\
\hline & & & her-3a22 $(121.54,0.15)$ \\
\hline
\end{tabular}




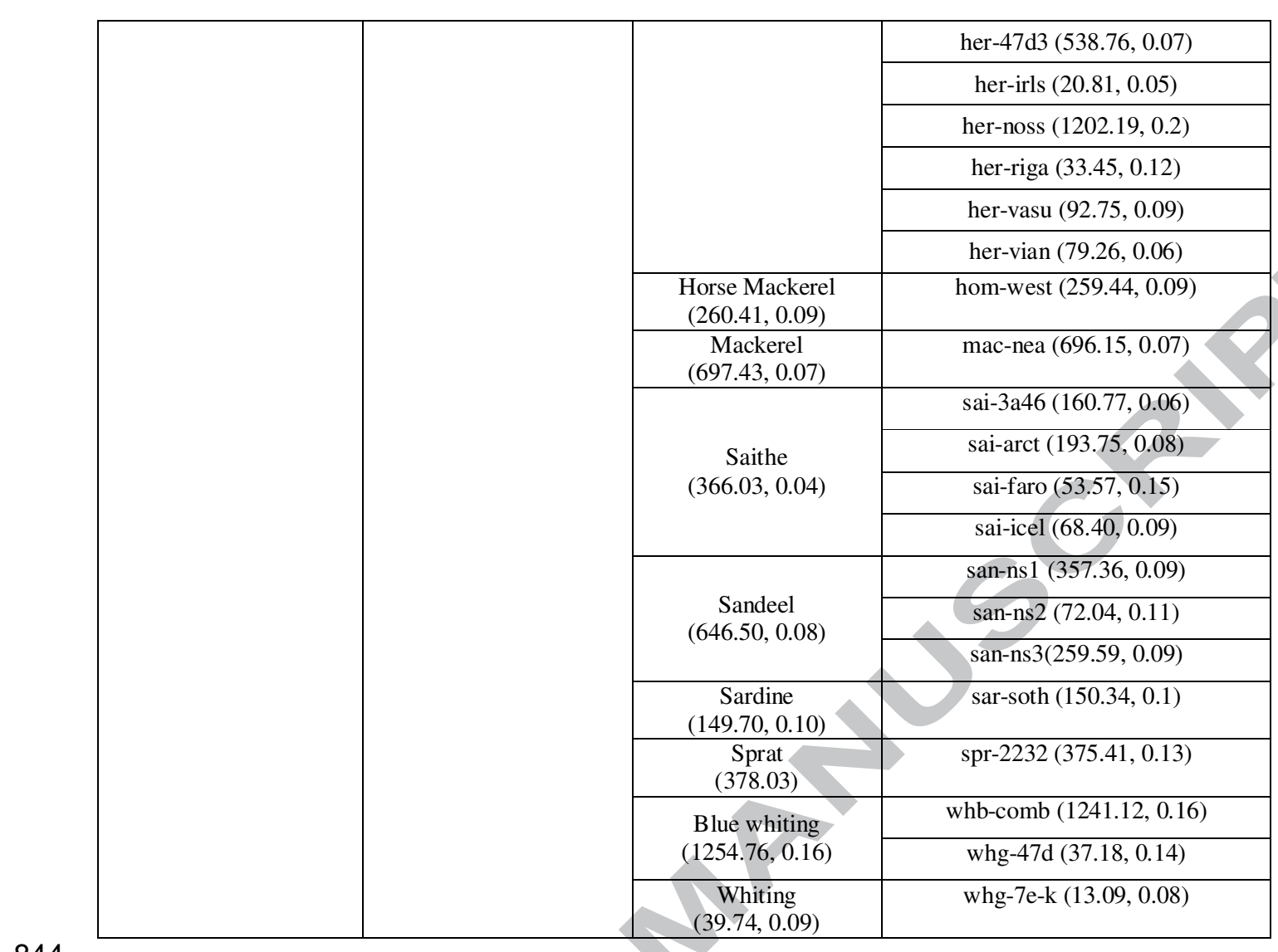


846 Table 2. Data used to parameterize the bioeconomic model. Catch and value were built 847 combining data from international databases (FAO and Sea Around Us). Cost parameters are 848 from Lam et al (2011). Additionally, the net profits of EU member states as reported in the 849 Annual Economic Report on the European Fishing Fleet (JRC, 2012).

850

\begin{tabular}{|c|c|c|c|c|c|c|c|}
\hline Country & $\begin{array}{c}\text { Catch (t) } \\
(2010)\end{array}$ & $\begin{array}{c}\text { Value of catch } \\
\text { (MEur) }(2010)\end{array}$ & $\begin{array}{c}\text { Operational } \\
\text { costs (Eur/t) }\end{array}$ & $\begin{array}{c}\text { Total Costs } \\
(\text { Eur/t) }\end{array}$ & $\begin{array}{c}\text { Estimated Op. } \\
\text { profits (MEur) }\end{array}$ & $\begin{array}{c}\text { Estimated } \\
\text { Net Profits } \\
\text { (MEur) }\end{array}$ & $\begin{array}{c}\text { Net Profits } \\
\text { AER, 2010) }\end{array}$ \\
\hline Belgium & 21,907 & 78.40 & $1,007.9$ & $2,139.1$ & 56.32 & 31.54 & -8.2 \\
\hline Denmark & 827,936 & 309.88 & $1,001.4$ & $1,147.4$ & -519.23 & -640.12 & -34.1 \\
\hline Estonia & 89,752 & 32.61 & 765.2 & 936.1 & -600.90 & -742.46 & 8.1 \\
\hline Finland & 121,169 & 24.54 & 980.1 & $1,176.7$ & -63.42 & -81.07 & 1.2 \\
\hline France & 312,162 & 731.22 & $1,053.5$ & $1,259.9$ & 603.58 & 578.57 & -5.5 \\
\hline Germany & 193,536 & 211.31 & $1,108.4$ & $1,324.9$ & -134.68 & -202.26 & 2.0 \\
\hline Iceland & $1,057,988$ & 697.00 & $1,119.6$ & $1,352.6$ & 480.32 & 435.23 & - \\
\hline Ireland & 285,527 & 63.65 & 981.6 & $1,169.0$ & -974.82 & $-1,173.11$ & -33.4 \\
\hline Latvia & 77,085 & 14.72 & 644.0 & 803.1 & -169.16 & -214.59 & 4.5 \\
\hline Lithuania & 21,371 & 19.92 & 673.0 & 828.5 & -31.96 & -43.95 & 8.2 \\
\hline Netherlands & 283,377 & 49.83 & $1,004.8$ & $1,206.4$ & 28.36 & 24.05 & 4.6 \\
\hline Norway & $2,555,186$ & $5,027.08$ & 610.7 & 733.8 & $4,854.01$ & $4,819.15$ & - \\
\hline Poland & 113,579 & 223.46 & 874.1 & $1,067.1$ & $-2,009.95$ & $-2,503.27$ & 30.9 \\
\hline Portugal & 201,730 & 102.33 & 801.4 & 949.8 & 11.31 & -5.55 & -38 \\
\hline Russian Fed & 997,827 & $1,305.52$ & $1,276.0$ & $1,533.7$ & $1,048.10$ & 996.12 & - \\
\hline Spain & 399,448 & 245.59 & $1,211.3$ & $1,427.4$ & -963.10 & $-1,178.74$ & -250.2 \\
\hline Sweden & 210,552 & 137.83 & 567.3 & 757.6 & -88.77 & -164.80 & -1.5 \\
\hline UK & 578,677 & 293.55 & 973.5 & $1,167.5$ & 88.57 & 47.72 & 74.6 \\
\hline Canada & $1,046,985$ & $1,416.26$ & $1,652.3$ & $1,825.5$ & 460.11 & 359.91 & - \\
\hline US & 743,143 & $1,444.67$ & $1,435.4$ & $1,604.5$ & 377.93 & 252.28 & - \\
\hline 85 & & & & & \\
\hline
\end{tabular}

851

852

853

854 
855 Table 3. Parameters for the bioeconomic model (Arnason, 2007; Arnason et al., 2009), 856 primarily derived from data for 2010 (see text).

857

\begin{tabular}{|l|c|c|c|c|}
\hline Parameter & Explanation & & Value & Unit858 \\
\hline $\mathrm{MSY}$ & & & 13.7 & $\mathrm{Mt} 859$ \\
\hline $\mathrm{K}$ & Carrying capacity & & 170 & $\mathrm{Mt} 860$ \\
\hline $\mathrm{G}(\mathrm{x})_{2010}$ & Biomass growth & & 0.283 & $\mathrm{t} / \mathrm{yr} 861$ \\
\hline $\mathrm{Y}_{2010}$ & Fisheries catches & & 10.14 & $\mathrm{Mt}$ \\
\hline Value $_{2010}$ & Value of catches & & 12.43 & $\mathrm{M} €$ \\
\hline Price $_{2010}$ & Base price of catch & & 1.22 & $€ / \mathrm{t}$ \\
\hline Profits & Fishery profits & & 0.63 & $\mathrm{~B} €$ \\
\hline $\mathrm{C}_{2010}$ & Cost of effort & & 11.8 & $\mathrm{M} €$ \\
\hline Price elasticity & Price elasticity & & 0.2 & $€ / \mathrm{Mt}$ \\
\hline Schooling $(\mathrm{b})$ & Schooling parameter & & 1 & - \\
\hline Ef $_{2010}$ & Fishing effort & & 1 & Normalized \\
\hline
\end{tabular}


Table A1. Necessary transformations to run the bioeconomic model using the parameters shown in Table 3 (Arnason, 2007; Arnason et al., 2009; Gordon, 1954; Schaefer, 1954).

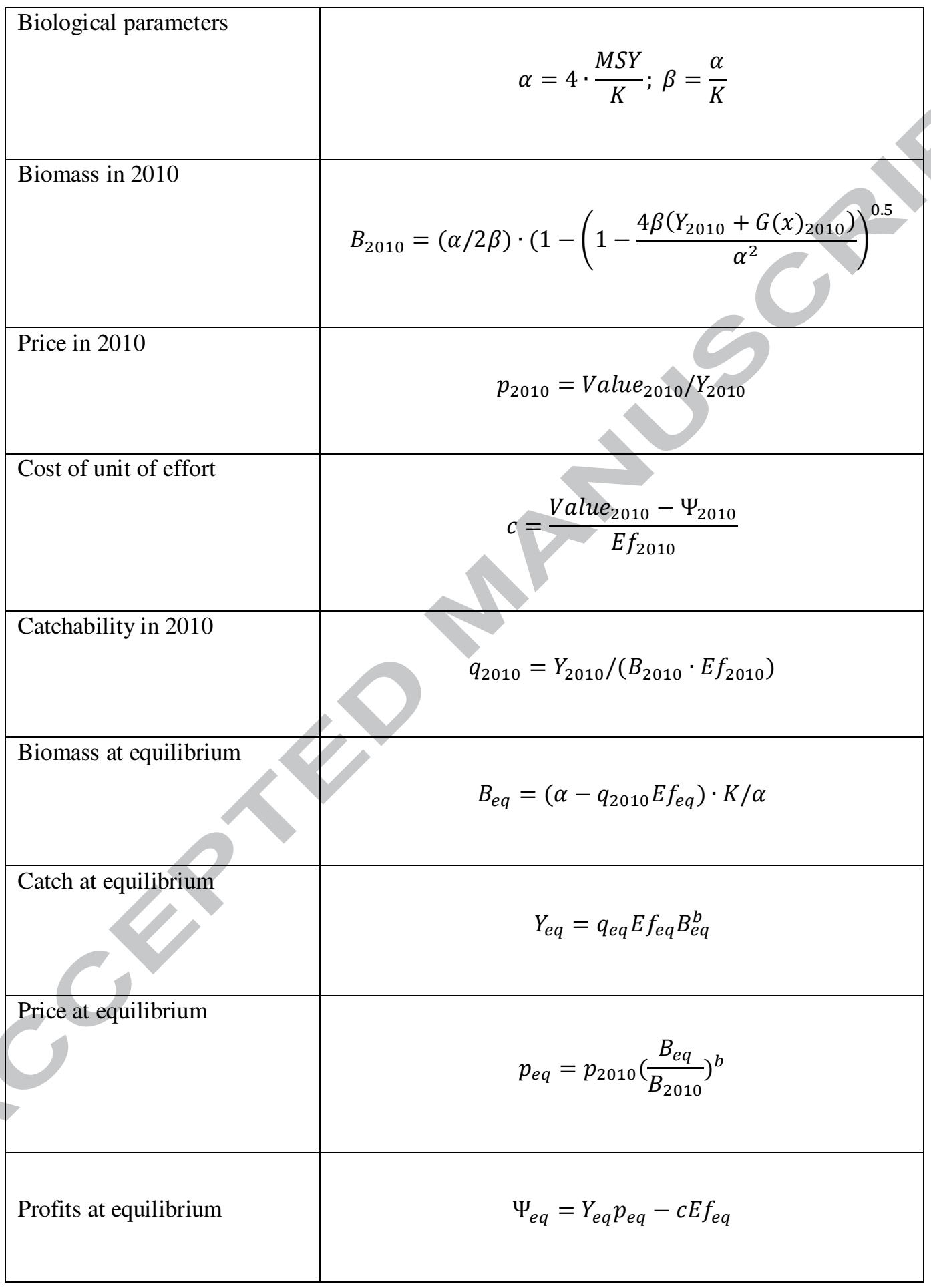

